\title{
EUROPEAN COMMUNITY POLICY ON COUNTERPART FUNDS
}

\section{Amos Tincani1}

\section{CF CURRENT PRACTICE}

The Community first became involved in the issue of $\mathrm{CF}$ through its food aid operations and, more recently, through import programmes in favour of adjusting ACP countries which are party to the Lomé Convention ${ }^{2}$. Over the years, a number of rules were adopted to ensure that $\mathrm{CF}$ were properly managed as regards both their constitution and utilization.

The original set of rules was defined in the context of food aid management (i.e. they apply to food aid receiving countries - ACP or other): the Council Regulation on food aid of December 1986 as well as the two Council Resolutions on food security in subSaharan Africa of November 1988, and on food aid guidelines of November 1989, respectively.

The legal framework provides for detailed rules on pricing and accounting as well as on use. On the latter point, priority is to be given to the financing of specific projects and programmes that promote national food production. An additional legal basis is provided by the Lomé IV Convention (which applies only to the ACP countries, i.e. to the sub-set of developing countries). Even though CPF are mentioned in several sections of the Convention (Art. 51 (b) on food aid; Art. 211 (3) on Stabex and Art. 240 (1) (a) on Sysmin), the main provisions are contained in Articles 224 (d) and 226. These articles stipulate that CPF generated from the various Community instruments should be used for targeted budgetary support. Art. 226, in particular, provides for a longish list of possible uses, but most of them can be clustered under the heading of the social dimension of adjustment. The Lome IV provisions therefore represent an evolution in respect of the food aid provisions from specific project financing towards budgetary support.

Even though the legal framework is complex and sometimes applies to different instruments and/or different sets of developing countries, it has evolved over the years towards a more coherent and integrated approach in the context of the budgetary process.

In terms of flows, a recent study by Maxwell shows that

This article represents the views of the author and not necessarily those of the EC.

2 The Lomé Convention is an international agreement between the European Community and its Member States on the one hand, and 69 developing countries in Africa, the Caribbean and the Pacific
Community CF-generating aid is about ECU $400 \mathrm{~m}^{3}$ per annum, equivalent to between 10 and 15 per cent of all Community aid. In 1989-90, 60 per cent of the total was generated by food aid and the balance by import programmes, though the latter was growing faster. Indeed if one judges by current annual commitments (ECU $180 \mathrm{~m}$ for food aid and ECU $260 \mathrm{~m}$ for import programmes) the relative weight of the two instruments will soon be reversed. In 1988-90 five countries accounted for 44 per cent of all CF and in 12 countries $\mathrm{CF}$ accounted for more than 30 per cent of all EC aid to the country. This typically occurred in countries that benefit from both food aid and import programmes.

\section{ISSUES ARISING FROM COMMUNITY EXPERIENCE}

In the implementation of its CF-generating aid, the Community has been confronted with two sets of problems: on management and macroeconomic consistency.

On the first issue, it must be recognized that various legal provisions have not prevented the emergence of difficulties as a result of non-adherence to the rules which has sometimes led the Commission to suspend food deliveries to some countries - as well as excessive delays in the use of funds.

The situation with regard to current practice has been reviewed in two papers by Knop. The first paper shows that the leakage from CF averaged 25 per cent in $1987 / 88$, that is to say that the amount credited to the CF account was 25 per cent less than what would be expected, comparing the delivery value of food aid with its local currency value at the official exchange rate. The second paper is a more general review of $\mathrm{CF}$ accounting practices. It shows that deductions are often high, although they have fallen substantially after the introduction of the 1986 regulations. Long delays in crediting CF have also been identified in some cases and only a third of countries are reported to place CF in an interest-bearing account. More importantly, the report shows poor monitoring of expenditures as well as insufficient planning which, in turn, generates an

(known as ACP countries) on the other. The recently approved 4th Lomé Convention contains new provisions for a structural adjustment support through import programmes which have become a major source of CF creation.

$3 \mathrm{ECU}$ is approximately $\mathrm{UK} £_{0} 0.70$. 
accumulation of unspent funds. In terms of destination, the report indicates that over two thirds of CF are used in the agricultural and rural development sectors.

The fact that CF are managed by the staff of the Commission's Delegation in the recipient country on top of the normal flow of project and programming assistance may sometimes have caused difficulties in ensuring rigorous follow-up. In the circumstances, the management problems identified by the two papers are relatively minor.

Possibly the 'best current practice' is exemplified by 'Operation Flood', whereby a multi-year programme of skimmed milk powder and butteroil has been extended to India with a view to help that country set up a dairy industry.

During the first and second phases, the total value of food products delivered exceeded ECU $500 \mathrm{~m}$, to which should be added another ECU $200 \mathrm{~m}$ of World Bank loans. The EC food aid for the present third phase (ending in 1994), is ECU $144 \mathrm{~m}$. Devised by Indian dairy experts, Operation Flood is a good example of how food aid can be used to fund a development project. Its purpose is to:

- raise milk producers' incomes by organizing them into cooperatives and eliminating middle men;

- raise milk production in rural areas (creating a 'flood' of milk) to help meet urban demand on a regular year-round basis.

More recently, a source of concern has arisen in certain countries, where the use of CF could undermine the pursuit of stabilization and adjustment objectives.

The growth in counterpart funds as a result of the increase of CF-generating aid, and the fact that they are generated faster than they are used, means that there is an excessive accumulation of these funds (all donors included) in some countries. Therefore, it is often no longer possible to separate the use of these funds from the macroeconomic context, especially in the case of countries implementing structural adjustment policies.

By way of example, the accumulation of counterpart funds generated by the aid of various donors accounted in 1990 for 20 per cent of the money supply in Guinea, 50 per cent in Madagascar and 91 per cent in GuineaBissau. The inflationary effect of massive expenditure of counterpart funds in such cases cannot be ignored. These three examples show that in the case of countries with adjustment programmes that have accumulated a sizeable volume of counterpart funds, donors cannot afford to adopt strategies that do not take into account the macroeconomic context as well as the monetary and financial imbalances in these countries.
From the macroeconomic point of view there is no doubt that $C F$ can affect the money supply: the accumulation of $\mathrm{CF}$ has, per se, a deflationary impact and their use an inflationary one

However, the reality of the situation in countries implementing adjustment programmes is more complex. Under IMF-supported programmes, CF are normally taken into account when the IMF calculates the government net position vis-a-vis the Central Bank, i.e. a key performance criterion aimed at capping government expenditure. In other words, the net position of the government is improved in proportion to the amount of CF generated by donor assistance.

At this point, if $\mathrm{CF}$ have not been allocated to expenditures specified within the approved budget, the government may in effect use the 'resources' generated by $\mathrm{CF}$ to finance any operation it chooses, within the overall ceiling on expenditure, by debiting its general account at the Central Bank - which does not require donor approval - rather than the special CF account, which requires prior donor approval.

The donor maintains a credit position in the $\mathrm{CF}$ account, but these resources have in fact already been used to finance the government's preferred expenditures, and cannot be used a second time without generating inflation. The only option is the sterilization of CF, i.e. to decrease the Treasury's debt vis-a-vis the Central Bank and accept as a consequence expenditures already executed.

Whether the government really has the option outlined above depends in practice on the donor's attitude. In most cases, the donor will be more than fully occupied with following up fresh allocations of aid and may be reluctant to suspend new aid because of problems with past $\mathrm{CF}$ use

But the root of the problem lies in the fact that the donor has not been associated with the policy dialogue on the budget and its spending priorities have not been taken into account when drawing up the budget.

\section{THE RECENT COMMISSION INITIATIVE}

Confronted with the challenge of efficiently administering a growing amount of CF-creating aid, as well as of ensuring that its CF policy does not run counter to the stabilization and adjustment objectives of adjusting countries, the Commission has recently taken two initiatives:

- the first within the Community, led to a Resolution on CF policy which was approved by the EC Ministers for Development on May 27, 1991;

- the second, within the SPA group of donors, led to the adoption of guidelines on CF on April 17, 1991. 
The two exercises have been instrumental in bringing to the surface the many myths and illusions held by members of the two opposing 'schools', those who support the earmarking of $\mathrm{CF}$ for specific expenditures, and those who oppose earmarking. In particular, the discussions have shown that:

i blocking counterpart funds on a double-signature account gives an illusion of control by the donor which can easily be circumvented by parallel monetary creation;

ii fungibility, a much invoked principle by the opponents of earmarking, does not always apply. Indeed, fungibility does not work when a donor favours an expenditure that a recipient government had not planned. In order to comply with that request - within a given overall ceiling on expenditure set by the IMF the recipient government has to reduce expenditure elsewhere;

iii the technique of earmarking may not be a very effective means, but the objective of increasing the efficiency and equity of public expenditure remains valid;

iv the 'quality control' of the IBRD and the IMF on Public Expenditure of adjusting countries varies considerably from case to case and generally needs to be improved. Pursuing development objectives through the budgetary process is indeed a long and difficult task;

$\mathbf{v}$ the fact of not earmarking means in practice accepting the budgetary priorities of the recipient country as defined in conjunction with the Bretton Woods Institutions.

Above all, the debates have shown that the relaxation of earmarking has to go hand in hand with the improvement of the budgetary process, in terms of composition of the budget on efficiency and equity grounds, as well as implementation, monitoring and review. Provided that there is a clear understanding on the level and structure of public spending, then fungibility applies and earmarking becomes an unnecessary administrative burden.

The main principles of the Guidelines and of the Resolution are:

i a single CF policy - irrespective of the origin - as part of the budgetary process; CF indeed lose their 'colour of origin' (food aid; import programmes) and simply become budgetary resources. As such, they are therefore a part of the budget policy which is in turn a major component of the reform policy;

ii for non-adjusting/marginal beneficiaries of CF, the possibility remains of pursuing the traditional microeconomic approach (earmarking for specific, discrete projects, without being too concerned about wider budgetary issues);

iii for the countries pursuing adjustment efforts, consistency with structural adjustment objectives as agreed with the Bretton Woods Institutions, taking into account the views of the other adjustment donors;

iv flexible and pragmatic coordination between the Bretton Woods Institutions and the other relevant donors in assisting recipient adjusting countries in the formulation and implementation of appropriate budgetary policies. This probably is the most delicate and complex principle to implement, as it requires that the Bretton Woods Institutions and the recipient countries involve the other relevant donors in the policy dialogue over the budget. Indeed, pleading the case for an increase in the budget size may create problems with Washington, while pleading the case for a change in its composition may create problems with the adjusting country;

$v$ use of a single CF account by each donor to be used to finance on-budget priority public expenditures. In certain situations, sterilization should be considered. The use of the single account would, for many donors like the Community, considerably streamline the CF management. As far as expenditure items are concerned, no out-of-budget expenditure should be supported.

vi where possible, a switch to multi-year food aid and, subject to policy performance, adjustment assistance. This would in turn produce a steady flow of CF.

The SPA guidelines ${ }^{4}$ are attached for reference at Annex 1.

\section{THE TASK AHEAD}

The Commission, for its part, is called upon to implement the above principles. In this context its objectives for the next few years should be twofold:

i for all CF recipients, improve its financial follow-up of $\mathrm{CF}$, in terms of constitution, accounting, reporting, etc. The single CF account should be the tool through which to improve CF management;

ii for adjusting countries, increasingly participate in public expenditure reviews.

Indeed as part of its involvement in structural adjustment support, the Commission will be increasingly called upon to participate in public expenditure reviews alongside the IMF and the Bank

adjusting countries in sub-Saharan Africa. In view of the fact that, collectively, the SPA group of donors are the major providers of $C P F$-creating aid in sub-Saharan Africa, the Commission felt that it was important that the new policy extend to them as well.
The Special Programme of Assistance (SPA) for low-income debt distressed African countries south of the Sahara, is a collaborative effort led by the World Bank which comprises the main bilateral and multilateral donors as well as financial instirutions that support 
and the other relevant donors.

Its task, however, will not be easy. In addition to improving financial management - which is an important challenge of its own - the Commission will have to contribute to what is presently done mainly by the Bank in terms of public expenditure reviews. In particular it will have to assist recipient countries in, first, putting together proper sectoral policies in key sectors (education, health, food security, etc.) and, second, in properly reflecting them in the budget in terms of level and composition of expenditure. It will probably take a few years for the Commission to make its impact felt.

\section{REFERENCES}

CEGOS-IDET, 1989, 'Etude sur l'impact economique et la gestion des fonds de contrepartie', Report to the Commission, Brussels

Goreux, L. M., 1990, 'Counterpart fund policies in a macroeconomic context', Report to the Commission, Washington DC

Knop, M., 1989, 'Rapport final sur la gestion des fonds de contrepartie engendres par la vente d'aide alimentaíre de la C.EE', Final Report to the Commission, Brussels

-1990 , 'Final report on the use of counterpart funds arising from the sale of Community food aid in 1987, 1988 and 1989' - Report to the Commission

Maxwell, S., with Owens, T., 1991, 'The developmental uses of counterpart funds', Discussion Paper No 289, IDS, Sussex
European Community, 1986, Council Regulation No. 3972/86 on food aid policy and food aid management

-1988, Council Resolution of 23 November 1988 on food security policy in sub-Saharan Africa

-1989 , Council Resolution of 21 November 1989 on food aid guidelines

-1990 , 'Discussion paper on counterpart funds, prepared by the Commission staff for discussion in the framework of the SPA'.

-1990 , 'Use of counterpart funds generated by the various development assistance instruments', commission staff working paper submitted to the council

-1991, Council Resolution of 27 May 1991 on the use of counterpart funds generated by the various development assistance instruments

\section{ANNEX 1}

\section{SPA WORKING GROUP ON COUNTERPART FUNDS GUIDELINES ON COUNTERPART FUNDS}

\section{A INTRODUCTION}

1 The SPA discussions of October 1990 raised a number of points related to the management of counterpart funds (CF), which the donor community should address in the context of the SPA countries. Based upon SPA 2 pledges, CF creation for the SPA countries was estimated to be substantial, amounting to the equivalent of US $\$ 4$ billion annually derived from adjustment assistance of all SPA donors, mainly in the form of commodity imports.

i The donor-recipient agreements on CF management for the SPA countries should be consistent with their structural adjustment policies and reforms within a framework of external adjustment, stabilization and growthoriented developmental objectives agreed to with the Bretton Woods Institutions (BWIs), taking into account the views of the donor community.

ii Donors earmark the use of $\mathrm{CF}$ in order to increase efficiency and equity of public expenditures. Under a structural adjustment programme, the efficiency and equity of public expenditure (including both recurrent and investment outlays) are to be achieved by setting their level and prioritizing their composition within a coherent framework of macroeconomic and developmental objectives. Such expenditure programmes are also subject to monitoring and periodic reviews. As progress is achieved along these lines, the case for earmarking CF for specific uses decreases.

iii Some donor agencies, dependent on budgetary appropriations and accountable for the use of public funds, may be subjected to strict legal requirements on $\mathrm{CF}$ use; hence, they may find it difficult to adopt a policy of total unearmarking of CF use. As with the case of SPA donors' harmonizing procurement procedures for adjustment assistance, it is hoped that a set of consensus guidelines for the use of CF would assist individual donors to review their bilateral procedures leading towards greater harmonization.

iv In providing support for the priority public expenditure programmes of recipient countries, the donors and the BWIs should coordinate their approaches in a flexible and pragmatic way. 
2 In view of the fact that the Development Assistance Committee of the OECD is presently working on the draft principles for programme assistance, it is suggested that any agreed SPA guidelines for the management of CF be submitted as an input for the DAC exercise. The proposed SPA guidelines are presented below. Although they have been written in respect of adjusting countries in general and SPA countries in particular, many of the same principles apply to non-adjusting countries who receive programme food aid.

3 The satisfactory implementation of budgetary targets and expenditure priorities requires these to be clearly formulated and that there is adequate budgetary monitoring and control processes.

4 It is proposed that the new guidelines be implemented in SPA countries. It is moreover suggested that a special effort should be made in a few countries to be chosen as test-cases ${ }^{1}$ on the basis of the following criteria:

- the number of donors present;

- the size of CF relative to money supply and the budget;

- the adequacy of the budgetary monitoring and control process.

5 The progress made in the application of the guidelines could be assessed after one year. This could in turn lead to an update and extension of the guidelines as appropriate. In this context, most working group participants suggest that, on the basis of this assessment, it would be desirable to go one step further. In particular they suggest that, in SPA countries with demonstrated capacity (or along with appropriate steps taken to strengthen such capacity) for public expenditure planning and effective budget implementation, participating donors could establish, as a standard procedure, a single CF account for the deposit of all counterpart funds. CF from this account would be released in support of a priority expenditure programme as defined under Guideline 1.

\section{B GUIDELINES ON MANAGEMENT OF CF IN ADJUSTING COUNTRIES}

1 CF generated from foreign assistance are budgetary resources accruing to the recipient country to be managed in the framework of a single and coherent budgetary policy (investment and recurrent budgets and, through them, the operations of the parastatal sector) in the context of a policy reform programme. Within such a budgetary framework, an important component should be a priority public expenditure programme that would broadly include outlays for investment, development and economic rehabilitation projects, and recurrent operations for essential maintenance and other productive socioeconomic services.

2 Bilateral donor-recipient agreements on $\mathrm{CF}$ management must be consistent with the objectives of external adjustment, non-inflationary growth, and the priority public expenditure programme agreed between the recipient country and the BWIs, taking into account the views of the donor community. Donors should support reform policies, including budgetary policy, when seeking agreement on CF management.

3 The effectiveness of adjustment assistance depends on the policies and institutional reforms implemented, including those related to public expenditures. The recipient country, with the assistance of the donor community and the BWIs, should closely monitor public expenditure programmes, both investment and recurrent, to ensure that public sector resources are channelled in accordance with the priorities defined in the budget to address efficiency and equity considerations.

Effective procedures for monitoring budget implementation should be ensured through provision, where appropriate, of technical assistance.

4 In providing recipient countries help with budget policy formulation, implementation, and monitoring for both investment and recurrent outlays, the BWIs should take into account the donors' views and financial support to a given country, at a sufficiently early stage in a flexible and pragmatic way.

5 All CF of each donor should be consolidated in a single account by donor at the Central Bank consistent with that donor's statutory regulations. They should be used to finance broad budgetary headings of on-budget priority public expenditures as defined under Guideline 1.

6 At the time of formulating next year's budget and its priority expenditure programme, the appropriate treatment of any outstanding balance on the $\mathrm{CF}$ account at the end of a fiscal year as well as the new $\mathrm{CF}$ creation projected for the following fiscal year would need to be considered. The use of the CF account would continue to be flexible and consistent with the objectives of external adjustment and non-

\footnotetext{
1 The proposals made concern the following countries: Burundi, Ghana, Madagascar, Mozambique and Rwanda.
} 
inflationary growth under the adjustment programmes agreed with the BWIs. It should be recognized that in the light of these macroeconomic objectives, it may become necessary for donors to sterilize totally or partially in a coordinated way the past accumulations of $\mathrm{CF}$ and/or the new creation of CFs.

7 In order to ensure an efficient CF management, the donor and the recipient to the extent possible, should plan multi-year rolling programme of food aid, and, subject to adequate policy performance, of adjustment assistance.
8 In the case of commodity/food aid, donors should value commodities either on the basis of import parity prices or on the basis of a pricing policy agreed under the policy reform programme, and should agree on a common time period by which CF have to be deposited.

9 It is important that the role of CFs in generating revenues for the government budget can be monitored. Donors should agree with the recipient government in each SPA country on a common format for reporting on CF payments due to be collected from importers, and amounts actually paid. 